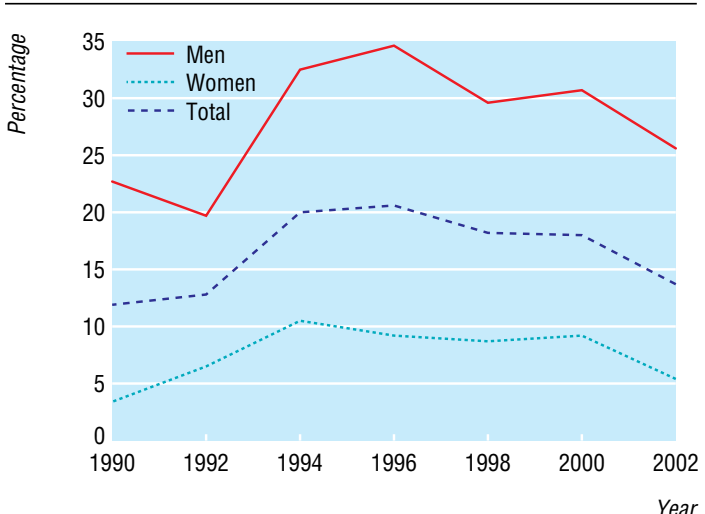

Fig 3 Percentage of adults who drink spirits every week, Estonia, 1990-2002

As a result, there is some evidence of a positive impact on the health of the population, but some health indicators have not improved.

To be effective, public health reforms must be supported by political decisions that make it easier for people to make healthy choices. A comprehensive national health policy and strategy is still lacking in Estonia. The evaluation of the health programmes and projects is often complicated because the objectives have not been clearly formulated and lack measurable targets. Priority setting expressed in a clearly stated health policy and strategy is needed. The strategy should be evaluated systematically to find the most effective way to improve the population's health.

Contributors and sources: KP is assistant professor of health care management at the University of Tartu in Estonia and doctoral student at the Nordic School of Public Health in Sweden. She is preparing a doctoral thesis on health system development in Estonia. GM is currently a member of the managing board of the ERGO life and non-life insurance company in Estonia, Latvia, and Lithuania. He has worked in the field of social insurance and welfare in Estonia, and as a consultant on social policy in different countries in central and eastern Europe. RA is professor of health management at the Nordic School of Public Health in Sweden. He has also worked as an expert for the European Union in different countries in central and eastern Europe countries. The idea of this article was developed and a first draft written by KP after revisiting previous studies and health statistics. The subsequent drafts and the final draft was jointly written by all authors. KP is guarantor.

Funding: None.

Competing interests: None declared.

Gonzales Block MA. Comparative research and analysis methods for shared learning from health system reforms. Health Policy 1997;42:187209.

2 Public health and family medicine. WHO/World Bank seminar 28-29 November 1994, University of Tartu, Estonia. Tartu: Trükiekspert Ltd, 1994.

3 Estonian Centre for Health Education and Promotion. Health promotion in Estonia. Tallinn: Estonian Centre for Health Education and Promotion, 1996.

4 Saava A. History of public health research in Estonia. Eur J Public Health 2000;10:64-7.

5 Köhler L, Eklund L. BRIMHEALTH. A successful experience in NordicBaltic cooperation in public health training. Eur J Public Health 2002; 12:152-4.

6 McKee M, Nolte E. Lessons from health during the transition from communism. BMJ 2004;329:1428-9.

7 Põlluste K, ed. Public health in Estonia. Tartu: Elmatar Publishing House, 1998.

8 Kaasik T, Andersson R, Horte LG. The effects of political and economic transitions on health and safety in Estonia: an Estonian-Swedish comparative study. Soc Sci Med 1998;47:1589-99.

9 Lindsay M. Estonia races to halt multidrug-resistant TB before HIV takes hold. Bull World Health Organ 2002,80:519.

10 Lipand A, Kasmel A, Tasa E, Leinsalu M, Uutela A, Puska P, et al. Health behaviour among Estonian adult population, spring 1994. Helsinki: National Public Health Institute, 1995. (B5/1995.)

11 McKee M, Pomerleau J, Robertson A, Pudule I, Grinberga D, Kadziauskiene K, et al. Alcohol consumption in the Baltic Republics.J Epidemiol Community Health 2000;54:361-6.

12 World Bank. Staff appraisal report, Estonia, health project. Washington: World Bank, 1995. (Report No. 13297-EE.)

13 Ministry of Social Affairs. Estonian Health Statistics 1992-1999. Tallinn: Ministry of Social Affairs of Estonia, 2000.

14 Ministry of Social Affairs. Estomian Health Statistics 2000-2002. Tallinn: Ministry of Social Affairs of Estonia. 2003 .

15 Lipand A, Kasmel A, Kivilo M, Tasa E, Berg M-A, Peltoniemi J, et al. Health behaviour among Estomian adult population, spring 1990. Helsinki: National Public Health Institute, 1992. (B1/1992.)

16 Kasmel A, Lipand A, Markina A. Health behaviour among Estonian adult population, spring 2002. Tallinn: Estonian Centre for Health Education and Promotion, 2003.

17 Saltman RB, Busse R, Mossialos E, eds. Regulating entrepreneurial behaviour in European health care systems. Buckingham: Open University Press, 2002 (European Observatory on Health Care Systems series)

18 Liu Y, Rao K, Fei J.Economic transition and health transition: comparing China and Russia. Health Policy 1998:44:103-22.

19 Värnik A, Kõlves K, Wasserman D. Suicide among Russians in Estonia: Värnik A, Kõlves K, Wasserman D. Suicide among Russians in Esto

20 McKee M, Shkolnikov V. Understanding the toll of premature death among men in Eastern Europe. BMJ 2001;323:1051-5.

21 Leinsalu M, Vagero D, Kunst AE. Estonia 1989-2000: enormous increase in mortality differences by education. Int J Epidemiol 2003;32:1081-7.

\title{
Transition and public health in the Slovak republic
}

\author{
Gabriel Gulis, Jarmila Korcova, Peter Letanovsky, Daniela Marcinkova
}

The socioeconomic and environmental changes arising from transition have affected public health. Improvement has started but there is still a long way to go

Like other Central and Eastern European countries, the Slovak Republic is in transition from a directive, centralised, political system to a democratic, market economy based system. However, since the break-up of the former Czechoslovakia on 1 January 1993, the republic is also undergoing transition from the federal system of policy making and leadership to an independent sovereign state (infrastructural transition). The development of a fully independent health sector within the Slovak Republic has posed serious challenges for public health policy makers and practi- tioners. We describe the main steps and changes during transition and discuss the achievements and tasks ahead.

\section{Legislative reform}

In 1994, an update of the act for the protection of human health restructured the public health system. Responsibility was delegated to the Ministry of Health, the main hygienist of the Slovak Republic, and regional hygienists. The National Office of Public Health currently has 36 regional offices. A new public
Unit of Health Promotion Research Institute of Public Health, University of Southern Denmark, Niels Bohrsvej 9-10, 6700 Esbjerg, Denmark

Gabriel Gulis associate professor continued over BMJ 2005;331:213-5 
Department of Hygiene and Epidemiology, Faculty of Health Care and Social Work, Trnava University, Trnava, Slovak Republic Jarmila Korcova deputy head

Daniela Marcinkova research and teaching assistant

Ministry of Health, Bratislava, Slovak Republic

Peter Letanovsky research assistant Correspondence to: G Gulis ggulis@ health.sdu.dk

Health status and health determinants in Slovak and Czech republics

\begin{tabular}{|c|c|c|c|c|}
\hline & \multicolumn{2}{|c|}{ Slovak Republic } & \multicolumn{2}{|c|}{ Czech Republic } \\
\hline & 1993 & 2002 & 1993 & 2002 \\
\hline \multicolumn{5}{|l|}{ Life expectancy at birth: } \\
\hline Boys & 68.43 & 69.91 & 69.33 & 72.15 \\
\hline Girls & 76.93 & 77.84 & 76.53 & 78.79 \\
\hline \multicolumn{5}{|l|}{ Life expectancy at 65 : } \\
\hline Men & 13.19 & 13.27 & 12.59 & 14.01 \\
\hline Women & 16.86 & 17.06 & 16.02 & 17.41 \\
\hline \multicolumn{5}{|l|}{$\%$ of population self assessing health as good: } \\
\hline Men & NA & 74.6 & NA & 57.45 \\
\hline Women & NA & 61.71 & NA & 52.72 \\
\hline \multicolumn{5}{|l|}{$\%$ of daily smokers among population aged $\geq 15$ : } \\
\hline Men & $32.5^{\star}$ & $44.1 \dagger$ & 32.2 & $30.9 \ddagger$ \\
\hline Women & $16.3^{*}$ & $14.7 \dagger$ & 21.3 & $20.4 \ddagger$ \\
\hline Pure alcohol consumption (I/person) & 9.32 & $9.8 \dagger$ & 12.62 & $13.59 \ddagger$ \\
\hline$\%$ of total energy available from fat & 32.78 & $34.65 \dagger$ & 34.22 & $34.06 \ddagger$ \\
\hline$\%$ of total energy available from protein & 11.45 & 10.01 & 12.29 & 11.74 \\
\hline Average amount of cereal available per person (kg/year) & 107.3 & 128.4 & 108.3 & 112.6 \\
\hline Average amount of fruits and vegetables available per person ( $\mathrm{kg} / \mathrm{year}$ ) & 120.4 & 134.4 & 131.6 & 142 \\
\hline Unemployment rate (\%) & 12.9 & 13.7 & 4.3 & 7.5 \\
\hline UNDP human development index & NA & 0.825 & NA & 0.843 \\
\hline Salmonellosis cases per 100000 & 220.09 & 398.28 & 417.65 & 476.4 \\
\hline$\%$ of population whose homes are connected to water supply system & NA & 82.1 & NA & 86.2 \\
\hline$\%$ of population with access to sewage system, septic tank, or other hygienic means of sewage disposal & NA & 55.2 & NA & 74.9 \\
\hline
\end{tabular}

NA=not available, UNDP=United Nations Development Programme.

*Data for 1992

†Data for 1998.

fData for 2001.

health act is being prepared, which focuses more on health determinants, health promotion, and assessment of effect. It is expected to be passed this year.

Three major policy documents also passed through government and parliament during 19902004: the national health promotion programme in 1991, the state health policy in 2000, and the national environmental health action plan in 2001. The state health policy introduced the World Health Organization's Health for All policy into the country, and the environmental health action plan introduced major ideas to solve environmental health problems. All three documents share one common problem: no clear responsibilities or funding schemes have been developed to implement them.

\section{Education and research}

Before transition, most public health professionals were educated at the medical hygienic faculty of Charles University in Prague. Postgraduate schools in Prague and Bratislava offered different specialisations, including general and community health, occupational health, health of children and young people, food safety and nutrition, epidemiology of infectious diseases, social medicine, and health management. The main change in education began in 1993, with the opening of the public health programme at the faculty of health care and social work at the university in Trnava. Courses in public health have since opened at the Comenius University Medical School and Slovak Medical University in Bratislava.

Public health training is slowly approaching international standards. Summer schools (at the London School of Hygiene and Tropical Medicine, WHO, the University of Iowa, and others) and foreign fellowships have contributed greatly to the growth of a new generation of public health workers.

Research is an important part of public health, and is closely allied to education and practice. Major research institutes such as the Health Education Institute, the Nutrition Research Institute, and the National Health Promotion Centre were dissolved because of economic constraints at the end of the 1990s. Nevertheless, Slovak public health researchers are increasingly participating on international projects within US supported research schemes, the framework programmes of the European Union, and the recent European public health strategy. Another positive development is the establishment of the National Agency for Science and Research, which operates under internationally recognised rules for research funding. The agency has obtained increasing funding for national research in the past few years, rising from nothing in 2001 to $1.3 \mathrm{~m}$ koruny (£2.3m, €3.5m, $\$ 4.2 \mathrm{~m})$ in $2003 .{ }^{1}$

\section{Health status of population}

WHO's health for all database ${ }^{2}$ provides information on the health status of the Slovak Republic population, and also allows comparison with the Czech Republic, the historically closest partner. The table shows selected health status and health determinants.

Life expectancy increased less in the Slovak Republic than the Czech Republic during 1993-2002. The percentage of men who smoke regularly is higher in the Slovak Republic, and it has done less well than the Czech Republic on most of the health determinants listed in the table.

One of the explanations for slower progress may be the double transition. Most of the administrative institutions had to be established before they could 
take control of development. The best example for this is public health research funding, where the research funding agency had to be set up before funding could be generated. Another explanation is the size of transition. The unemployment data show that the Slovak Republic was hit harder by economic transition than the Czech Republic. The almost doubled incidence of salmonellosis in the Slovak Republic between 1993 and 2002 (although still lower than in the Czech Republic) reflects the damage done to agriculture by transition. The rise in salmonellosis incidence also raises questions about the effectiveness of the surveillance system and its ability to prevent disease. Pure reporting, as ensured by current legislation, is not enough.

\section{Attitudes and beliefs}

The transition from authoritative to democratic government increases the involvement of the public in decision making, both in general and also regarding public health. How do people assess their health? What do they think is crucial information for planning public health services? Three large surveys have been conducted in the Slovak Republic. The international health and behaviour survey is a questionnaire survey of health related behaviour, risk awareness, and associated attitudes that was carried out with university students worldwide. ${ }^{3}$ The former Institute of Health Education in collaboration with the Institutes of Hygiene and Epidemiology surveyed the general public's health attitudes, beliefs, and self assessed health in 1992, 1995 and $1998 .{ }^{4}$ The third survey was conducted as a pilot within WHO's European health interview study. Data from all these surveys show no significant differences between Slovak respondents and participants from other countries. ${ }^{5}$

Recently, a survey was conducted among key policy makers to assess their knowledge and awareness of major national and international health policy documents and the issue of health inequalities. The national response rate was only $1.7 \%$, and the best regional response only $17 \%$, suggesting low awareness about responsibilities regarding public health (D Marcinkova, G Gulis, 25th Association of Schools of Public Health in European Region annual conference, Caltanissetta, Sicily, September 2004). Among those who responded to the questionnaire, $43 \%$ had knowledge of national health policy documents and 18\% had knowledge of international documents. Only $40 \%$ of decision makers thought that their decisions influenced health, and just 10\% thought that they influenced health inequalities.

These data show that public health is still largely considered solely as a part of health care and therefore the responsibility of the ministry of health. Awareness of the wider influences on public health needs to be increased and truly intersectoral work introduced.

\section{A long path}

Transition is clearly a long path, which in fact may never end. It affects health by influencing all the major determinants, as shown by Dalghren in 1995 in his famous conceptual model of determinants of health as concentric circles. ${ }^{6}$ The main determinants of health in

\section{Summary points}

The health of Slovak citizens is slowly improving since transition

Training of public health professionals is increasing and improving in quality

Progress has been slowed by the need to set up new institutions as part of a second transition to a sovereign state

Lack of awareness and interest in public health issues among policy makers outside health needs remedying

the Slovak Republic are the same as those in other countries. Key factors enabling and obstructing advances in public health include overall macroeconomic and social conditions, general attitudes to public health, lack of multisectoral collaboration, and better consideration of policy options. ${ }^{7}$ International organisations have helped greatly with development of training, and the country now needs to make more efficient use of international help with legislation and shaping the attitudes of key decision makers.

We thank Robin Ungar, Center of International Rural and Environmental Health of the University of Iowa, for help and valuable comments during preparation of this article.

Contributors: GG designed the paper, wrote the health status part of the paper and edited other parts of it. JK wrote the education part of the paper. The legislation part of the paper is by PL. DM wrote the attitudes and beliefs part of the paper. GG is the guarantor.

Competing interests: None declared.

Agentúra na Podporu Vedy a Techniky. Celková podpora projektov v roku 2006. www.apvt.sk/index.php?pg = 206 (accessed 29 Jan 2005).

2 World Health Organization Regional Office for Europe. European health for all database. www.who.dk/hfadb (accessed 15 Jan 2005).

3 Wardle J, Steptoe A, Gulis G, Sartory G, Sek H, Todorova I, et al. Depression, perceived control, and life satisfaction in university students from Eastern and Western Europe. Int J Behav Med 2004;11:27-36.

4 Gulis G, Korcová J, Letanovský P, Majdan M, Marcinková D. Health-affair Gulis G, Korcová J, Letanovský P, Majdan M, Marcinková D. Health-affair
of public. First professional workshop, Slovak Association of Public Health, Košice 6.-7. November 2003. Medicinsky Monitor 2004;2:33.

5 Nosikov A, Gudex C. EUROHIS: developing common instruments for health surveys. Copenhagen: WHO Regional Office for Europe, 2003.

6 Dalghren G. European health policy conference: opportunities for the future. Vol 2. Intersectoral action for health. Copenhagen: WHO Regional Office for Europe, 1995.

7 Figueras J, McKee M, Cain J, Lessof S. Health systems in transition: learning from experience. Brussels: European Observatory on Health Systems and Policies, 2004.

\section{Endpiece}

\section{Patients' library in Leeds 1775}

The patients' library at the Leeds General Infirmary in 1775 had ten books. They included The Whole Duty of Man, The Great Importance of Religious Life, Ken's Directions for Prayer, and Stonehouse's Admomitions against Swearing etc. In 1783 an unknown benefactor gave 250 copies of Dr Adam's Tract on Confirmation and the Rational Communicant.

Anning S. The general infirmary at Leeds: the first hundred years 1767-1869. Edinburgh: E \& S Livingstone, 1963: 84

Submitted by Jeremy Hugh Baron, honorary professorial lecturer, Mount Sinai School of Medicine, New York 